\title{
LUGARES RETÓRICOS E MEMÓRIA NAS COMPOSIÇÕES DA DUPLA CAIPIRA ZÉ MULATO \& CASSIANO
}

\author{
Leonardo Vinícius de Souza Tavares (PUC-SP)
}

Esta comunicação está situada na área da Nova Retórica e tematiza o estudo dos lugares retóricos e da memória nas composições da dupla caipira Zé Mulato \& Cassiano. A problemática envolvida compreende os aspectos ligados às tensões materializadas nas canções, bem como ao trabalho com a memória, no sentido de encontrar os meios mais adequados ao tratamento de determinado tema, visando à persuasão. A pesquisa realizada fundamenta-se nos teóricos da retórica, especialmente em Perelman-Tyteca (1996) e Reboul (2004) e, no que diz respeito à memória, Yates (2016) e Le Goff (2014), e tem por objetivo geral analisar os lugares comuns e da memória existentes nas composições da dupla, a fim de determinar os efeitos patéticos que produzem no auditório. São objetivos específicos: a) identificar os sub-lugares da essência e do existente, presentes nas letras das canções; b) verificar os artifícios de memorização utilizados para atingir a eficácia do ato retórico. O procedimento metodológico é qualitativo com base teórico-analítica. O corpus selecionado é composto por uma composição produzida no ano de 2013. Os resultados obtidos, ainda provisórios, fazem parte de uma dissertação de mestrado em andamento. Contudo, a pesquisa permite algumas considerações: a) o uso dos lugares é eficaz, pois eles abrigam valores que asseguram o acordo com o auditório; b) o orador, valendo-se de técnicas mnemônicas, lança mão de variados recursos a fim de discorrer adequadamente sobre temas que escolhe comunicar e para persuadir.

PALAVRAS-CHAVE: Nova Retórica; Memória; Música Caipira 